\title{
Role of Micro Finance in Financial Inclusion
}

\author{
S Muralidhar* and K Sharada†
}

\section{Abstract}

Financial Inclusion (FI) is delivery of banking services at an affordable cost to the vast sections of disadvantaged and low income groups. When bankers do not give the desired attention to certain areas, the regulators have stepped into remedy the situation. This is the reason why the RBI is placing a lot of emphasis on Financial Inclusion.

Thus FI can be defined as "the process of ensuring access to financial services and timely \& adequate credit when needed by vulnerable groups such as weaker sections \& low income groups at an affordable cost." FI is about creating financial systems that support all people especially those previously excluded by providing them with access to financial services delivered in a convenient, reliable, and affordable manner.

Access to financial services has been recognized as a human right. Strengthening credit-delivery services and increasing their outreach has always been an important component of Indian development strategy. Despite the expansion of the wide network of the organized banking system deep into rural areas, a large number of the poor continued to remain outside the fold of the formal banking system. Both the market and the government failed to provide credit access to the poor. The evolution of microfinance was in response to the failure of institutional initiatives of rural credit and to the

* Department of Commerce and Management, Government College for Boys, Kolar-563101; dr_muralidhar_s@yahoo.co.in

† Department of Commerce and Management, Government College for boys, Chintamani-56312; sharada_gfgc@rediffmail.com 
weaknesses of the exploitative informal system of credit. To some extent, microfinance through SHG- Bank linkage model has been successful in providing credit access to the poor.

Keywords: Financial inclusion; Micro finance, Banking services; SHGs

\section{Introduction}

Consultative Group to Assist Poor (CGAP) defines micro finance as "The supply of loans, savings, and other basic financial services to the poor." People living in poverty like everyone else, need a diverse range of financial instruments to run their business, build assets, stabilize consumption, and shield themselves against risks. Financial services needed by the poor include working capital loans, consumer credit, and savings, pensions, insurance, and money transfer services.

People living below the poverty line, both in urban and rural areas can't accessible to the institutional credit to meet their financial requirements, due to lack of collateral. Indeed they have to depend upon local money lenders for their financial needs such as marriage in the family, illness or other emergency needs as the formal credit system of banks is beyond the reach of the poor people. This provides an opportunity for money lenders to exploit the situation by changing exorbitant rates of interests.

Micro Finance Institutions are seen as key players in delivering financial services to the poor people. They are regarded as new age solution to alleviate poverty and bring economic prosperity to the rural poor. Micro Finance is an indispensable tool to provide the poor and also the entrepreneurial people with necessary finance to start their own business.

A major thrust in recent years for improving lives of women folk and alleviating rural poverty through the non-governmental organizations (NGOs) in India is promoting micro finance through self help groups (SHGs). Currently around $75 \%$ of the credit supply comes through the SHG bank, largely financed by the National Bank for Agriculture and Rural Development (NABARD) and the rest comes from Micro Finance Institutions increasingly backed by 42 
commercial banks. Women's SHGs have become effective channels of credit for enterprise

\section{Objectives of the Study}

- To study the role of SHGs in Financial Inclusion

- To study the impact of SHG on savings, standard of living and other benefits accrued to its members.

- To study the improvement in the economic and social status of members.

\section{Statement of the Problem}

Micro Finance Programs are intended to reach the poor segments of the society as they lack access to financial services. Poor people generally can't access institutional credit due to lack of collaterals. This results into financial exclusion.

Recently the term financial inclusion is gaining moment as it focuses attention on the need to bring previously excluded people under the umbrella of financial institutions. The major Micro Finance program namely SHG bank linkage program has demonstrated its effectiveness in linking banks with excluded category of poor segments of population. Financial inclusion is not just credit dispensation, but it is about connecting the people with the banking system for availing bouquet of financial services including access to the payment system. Therefore the study has appropriately entitled as "Role of Micro Finance in Financial Inclusion".

\section{Scope of the Study}

The study is confined to the geographical area of Kolar District. Further the research is made to study the impact of the financial inclusion through the micro finance programs. SHG is the popular and biggest Micro finance program in India which is engaged in the delivery of financial services is taken as the scope of the study. 


\section{Methodology}

The present study used both primary and secondary data; the primary data is collected by administering the structured, pre-tested questionnaire to SHG members. In addition, personal interviews are also made wherever the necessity was felt.

The secondary source of data includes magazines bulletins, technical journals, and various websites.

\section{Sampling technique}

Stratified simple random sampling technique has been adopted for the study. Considering the vicinity of the location of rural areas where there is active working of WSHGs, the Kolar District by and large, inhabited by poor people is selected for collecting primary data. Further to ensure the authenticity of the data, enough care has been taken. While selecting the sample respondents from among the SHG members who have substantial exposure to SHG activities, were included in the total sample size. At the same time, care has been taken to see that the sample is the real representative of the total population of women SHGs in the Kolar District and selection of a unit into the sample size is made without any prejudice and free from all sorts of bias.

\section{Sample size}

The sample size is taken as 500 respondents. Since Kolar District constitutes 5 Taluks, 10 actively working Women Self-Help-Groups (WSHGs) were selected from each Taluk and from each group 10 members were selected. Hence the total respondents of 500 were taken as total sample size for the purpose of the study

\section{Plan of analysis}

To ensure the multi dimensional analysis of the primary data for throwing light on the various aspects of the research problem, specialized mathematical and statistical tools such as Mean, Standard Deviation, Chi-square test, etc. are used apart from the usual tools like averages, percentages, and Ratios. 


\section{Analysis and Interpretation of the Data}

Table: Talukwise number of SHGs selected for the study

\begin{tabular}{|l|c|c|c|}
\hline Taluks & $\begin{array}{c}\text { No. of } \\
\text { SHGs }\end{array}$ & $\begin{array}{c}\text { No. of } \\
\text { Respondents in } \\
\text { each SHG }\end{array}$ & $\begin{array}{c}\text { Total } \\
\text { Respondents }\end{array}$ \\
\hline Kolar & 10 & 10 & 100 \\
\hline Malur & 10 & 10 & 100 \\
\hline Mulbagal & 10 & 10 & 100 \\
\hline Bangarpet & 10 & 10 & 100 \\
\hline Srinivaspur & 10 & 10 & 100 \\
\hline Total & 50 & & 500 \\
\hline
\end{tabular}

There are five taluks in Kolar District viz.kolar, Malur, Mulbagal, Bangarpet, and Srinivaspur. SHGs are working actively in this District. As Kolar District comes under dry zones, mainly depends on rain water, majority of people in rural areas are in poor conditions; therefore SHGs are getting more popular in this area. Hence this area seems more appropriate for collections of primary data. Ten actively working SHGs are selected in each Taluk and 10 members from each SHG are selected randomly as respondents.

Table1: Reasons for joining SHG

\begin{tabular}{|l|c|c|}
\hline Reason to join SHG & Mean & Std dev \\
\hline To borrow loans & 2.22 & 1.14 \\
\hline To start income generating activities & 2.28 & 1.22 \\
\hline To save for future needs & 3.04 & 1.48 \\
\hline Have status in the society & 3.72 & 1.34 \\
\hline Meet house hold expenses & 3.73 & 0.96 \\
\hline Total & 3.00 & 1.23 \\
\hline
\end{tabular}

Majority of the respondents are joining to SHGs to meet the house hold expenses out of the loan taken in the groups with the highest mean difference of 3.73 followed by to have the status in the society with the mean difference of 3.72 to make savings with 3.04, to start income generating activities with 2.28 , and to take loans with the mean difference of 2.22 . 
Table 2: Sources of borrowing before becoming members of SHG

\begin{tabular}{|l|l|l|l|l|l|l|l|l|l|l|l|}
\hline & Total & \multicolumn{2}{|l|}{ Always } & \multicolumn{2}{l|}{$\begin{array}{l}\text { Most of the } \\
\text { times }\end{array}$} & \multicolumn{2}{l|}{ Sometimes } & \multicolumn{2}{l|}{ Rare } & \multicolumn{2}{l|}{ Never } \\
\hline $\begin{array}{l}\text { Prior } \\
\text { Borrows }\end{array}$ & Freq & Freq & $\%$ & Freq & $\%$ & Freq & $\%$ & Freq & $\%$ & Freq & $\%$ \\
\hline Neighbours & 500 & 50 & $10 \%$ & 120 & $24 \%$ & 125 & $25 \%$ & 53 & $11 \%$ & 152 & $30 \%$ \\
\hline $\begin{array}{l}\text { Relatives } \\
\text { \& Friends }\end{array}$ & 500 & 76 & $15 \%$ & 286 & $57 \%$ & 112 & $22 \%$ & 20 & $4 \%$ & 6 & $1 \%$ \\
\hline $\begin{array}{l}\text { Local } \\
\text { Money } \\
\text { Lenders }\end{array}$ & 500 & 423 & $85 \%$ & 77 & $15 \%$ & 0 & $0 \%$ & 0 & $0 \%$ & 0 & $0 \%$ \\
\hline
\end{tabular}

Sources of borrowing money before becoming member of SHG were also examined. $10 \%$ of the SHG members were always used to borrow from Neighbors, $15 \%$ from relatives \& friends, and $85 \%$ from local money lenders before becoming a member of SHG.

Table 3: Benefits derived by members after Joining to SHGs

\begin{tabular}{|l|r|r|r|r|r|}
\hline & Total & \multicolumn{2}{|c|}{ Yes } & \multicolumn{2}{c|}{ No } \\
\hline Benefits & Freq & Freq & $\%$ & Freq & $\%$ \\
\hline Development of saving habit & 500 & 500 & $100 \%$ & 0 & $0 \%$ \\
\hline Increase in additional income & 500 & 360 & $72 \%$ & 140 & $28 \%$ \\
\hline Freedom from debt & 500 & 425 & $85 \%$ & 75 & $15 \%$ \\
\hline $\begin{array}{l}\text { Access to resources and various } \\
\text { promotional assistance }\end{array}$ & 500 & 370 & $74 \%$ & 130 & $26 \%$ \\
\hline Better status in family and society & 500 & 380 & $76 \%$ & 120 & $24 \%$ \\
\hline $\begin{array}{l}\text { Self confidence and better } \\
\text { decision making power }\end{array}$ & 500 & 300 & $60 \%$ & 200 & $40 \%$ \\
\hline $\begin{array}{l}\text { Social cohesion and better } \\
\text { communication skill }\end{array}$ & 500 & 206 & $41 \%$ & 294 & $59 \%$ \\
\hline
\end{tabular}

In practice, all the SHG members expressed satisfaction regarding the benefits derived after joining the Self Help Group. All the members have realized and picked up saving habits, as it is compulsory to become a group member. SHGs are encouraging thrift and savings among the members which results in to mobilization of capital from gross root level. Next, majority of the SHGs felt that there was increase in additional income. $85 \%$ of the SHG stated that participating in SHG helped them in freedom from debt. Further, about $74 \%$ felt that they gained the benefit of access to resources and various promotional assistance programmes after joining the SHG. Majority of the respondents pointed out that they 
had better status in family and society after joining the SHG which constituted to $76 \%$. About $60 \%$ felt that their quality of life improved having positive impact on their self-confidence and making better decision in life.

Table 4: Physical assets hold by the members after becoming members of SHG

\begin{tabular}{|l|l|l|}
\hline Physical Assets & Multi Response Frequency & $\%$ \\
\hline Television & 500 & 100 \\
\hline Mixer Grinder & 125 & 25 \\
\hline Gas Stove & 225 & 45 \\
\hline Water Filters & 100 & 20 \\
\hline Bicycle & 125 & 25 \\
\hline Refrigerator & 100 & 20 \\
\hline Total & 500 & 100 \\
\hline
\end{tabular}

Physical assets are the indicators of the economic status of SHG members. Various types of physical assets hold by the SHG members after joining to the groups are also considered in this study. Almost $25 \%$ of the respondents have television, $45 \%$ of them have mixer grinders, $20 \%$ of the respondents own gas connections $\&$ gas stoves for cooking, and $20 \%$ possess water filters $25 \%$ bicycles \& $20 \%$ refrigerators.

Table 5: Table showing ways of empowerment after joining to SHGs

\begin{tabular}{|l|c|c|c|}
\hline Attributes & $\mathrm{N}$ & Mean & $\begin{array}{c}\text { Std. } \\
\text { Deviation }\end{array}$ \\
\hline Economic independence & 500 & 4.65 & 0.65 \\
\hline Standard of living has improved & 500 & 3.31 & 1.16 \\
\hline $\begin{array}{l}\text { Understand the banking operation and } \\
\text { knowledge on credit management }\end{array}$ & 500 & 1.75 & 1.11 \\
\hline Good public relation and social participation & 450 & 2.27 & 0.93 \\
\hline $\begin{array}{l}\text { Self expression-decision making in } \\
\text { community, village and house holds }\end{array}$ & 230 & 2.78 & 1.63 \\
\hline $\begin{array}{l}\text { Breaking social, religious and cultural } \\
\text { barriers }\end{array}$ & 168 & 2.49 & 1.29 \\
\hline Leadership qualities & 37 & 3.30 & 1.29 \\
\hline Skill up gradation and better technology & 101 & 3.33 & 1.33 \\
\hline
\end{tabular}

From the above chart it is clear that there is significant difference The above table shows that how the SHG members got empowered after joining the SHG by addressing the key attributes with their 
mean score. For the summarizing, the overall mean score shows that there the highest difference with the mean score of 4.65 which implies that Economic independence seems to play a major role in empowering the members after joining the SHG. In addition to that, it is also observed that the members seem to perceive and express their Standard of living, Leadership qualities, and their skill up gradation that has shown a positive note.

Table 6: Monthly income of members before and after joining to groups

\begin{tabular}{|l|c|c|c|c|}
\hline & \multicolumn{2}{|c|}{ Pre -SHG } & \multicolumn{2}{c|}{ Post-SHG } \\
\hline & Freq & $\%$ & Freq & $\%$ \\
\hline Below Rs 1000 & 150 & 30 & 75 & 15 \\
\hline Rs 1000-2000 & 100 & 20 & 80 & 16 \\
\hline Rs 2000-3000 & 80 & 16 & 90 & 18 \\
\hline Rs 3000-4000 & 60 & 12 & 100 & 20 \\
\hline Rs 4000-5000 & 60 & 12 & 90 & 18 \\
\hline Rs 5000 \& above & 50 & 10 & 65 & 13 \\
\hline Total & 500 & 100 & 500 & 100 \\
\hline
\end{tabular}

The above table shows perception of the respondents on monthly income levels. It was observed from the Pre-SHG study that the maximum percentage of respondents fall in the category with the monthly income of below Rs 1000 constituting to $30 \%$ and the next highest observed with the monthly income ranged between Rs $1000-2000$ category constituting to $20 \%$.The respondents of $12 \%$ each are earning the income ranges between Rs 3000-4000 and Rs $4000-5000$. Only $10 \%$ of the respondents are earning Rs 5000 and above as their monthly income. Among the Post-SHG, the study revealed that the maximum percentages of respondents are able to gain the monthly income of Rs 3000-4000. Next, the maximum respondents observed in the category of Rs 2000-3000 and Rs 40005000 were $18 \%$. On the whole, it is inferred from the results that the assistance of SHG was found to have enabled the members to enhance their earnings. These incremental levels of income have grown slightly prior to interventions under SHG. However, such a small increase in income has resulted in a significant rise in the group income. 
Table 7: Chi-square test for monthly income before \& after joining to SHGs

\begin{tabular}{|l|l|c|}
\hline \multicolumn{3}{|c|}{ Pearson Chi-Square Tests } \\
\hline & Chi-square & 45.77 \\
\hline Monthly Income - Pre-SHG and Post SHG & Df & 5.00 \\
\hline & Sig. & $0.00^{*}$ \\
\hline
\end{tabular}

Results are based on nonempty rows and columns in each innermost sub-table.

*The Chi-square statistic is significant at the 0.05 level.

The above results may be interpreted that monthly income seems to be influenced between Pre-SHG and Post SHG. Chi Square value showed 45.77 and sig value is. 0.00; thus it is significant at 0.05 levels. The results imply that there is dependence between PreSHG and Post SHG with respect to Monthly Income categorized.

Table 8: Monthly savings before and after becoming members of SHGs

\begin{tabular}{|l|c|c|c|c|}
\hline \multirow{2}{*}{} & \multicolumn{2}{|c|}{ Pre-SHG } & \multicolumn{2}{c|}{ Post-SHG } \\
\cline { 2 - 5 } & Freq & $\%$ & Freq & $\%$ \\
\hline No Savings & 385 & $77 \%$ & 0 & $0 \%$ \\
\hline Below Rs 100 & 5 & $1 \%$ & 310 & $62 \%$ \\
\hline Rs 100-200 & 30 & $6 \%$ & 20 & $4 \%$ \\
\hline Rs 200-300 & 40 & $8 \%$ & 34 & $7 \%$ \\
\hline Rs 300-400 & 30 & $6 \%$ & 50 & $10 \%$ \\
\hline Rs 400-500 & 10 & $2 \%$ & 35 & $7 \%$ \\
\hline Rs 500 \& above & 0 & $0 \%$ & 51 & $10 \%$ \\
\hline Total & 500 & $100 \%$ & 500 & $100 \%$ \\
\hline
\end{tabular}

The above table shows perception of the respondents on monthly savings ranges categorized. It is observed from the Pre-SHG study that the maximum percentage of respondents $(77 \%)$ had no savings at all, $1 \%$ of respondents are saving below Rs 100, 6\% each are saving between Rs 100-200, and the next highest observed is that only about $8 \%$ is able to have a monthly saving of Rs 200-300 and no one is saving Rs 500 \& above. Among the Post-SHG, the study revealed that the maximum percentages of respondents (62\%) are able to have a monthly savings of Below Rs $100.4 \%$ are saving between Rs 100-200. Next, 7\% each are making a monthly savings 
of Rs 200-300 and Rs 400-500, and 10\% each are observed in the category of Rs 300-400 and Rs 500 \& above. On the whole, it is inferred from the results that the assistance of SHG was found to have enabled the members to enhance their savings. There has been small increase in the monthly saving which will also result in a significant rise in the group income too. Though a very high level of monthly savings was not observed on an average, there is a dependency between Monthly Savings income and involvement in SHGs.

Table 9: Chi-square test for monthly savings before \& after joining to SHGs

\begin{tabular}{|c|c|c|}
\hline \multicolumn{3}{|c|}{ Pearson Chi-Square Tests } \\
\hline Monthly Savings - Pre-SHG and Post SHG & Chi-square & 752.69 \\
\hline & Df & 6.00 \\
\hline & Sig. & $0.00^{*}$ \\
\hline
\end{tabular}

Results are based on nonempty rows and columns in each innermost sub table.

*The Chi-square statistic is significant at the 0.05 level.

The above results may be interpreted that Monthly Saving seems to be inclined between Pre-SHG and Post SHG. Chi Square value showed 752.69 and sig value is. 0.00 , thus it is significant at 0.05 level. The results imply that there is dependency between Pre-SHG and Post SHG with respect to Monthly Savings range categorized.

Table 10: Monthly expenditure of members before and after joining to SHGs

\begin{tabular}{|l|r|r|r|r|}
\hline & \multicolumn{2}{|c|}{ Pre-SHG } & \multicolumn{2}{c|}{ Post-SHG } \\
\hline & Freq & \multicolumn{1}{c|}{$\%$} & \multicolumn{1}{c|}{ Freq } & \multicolumn{1}{c|}{$\%$} \\
\hline Below Rs 1000 & 385 & 77 & 310 & 62 \\
\hline Rs 1000-2000 & 5 & 1 & 20 & 4 \\
\hline Rs 2000-3000 & 30 & 6 & 35 & 7 \\
\hline Rs 3000-4000 & 39 & 7.8 & 50 & 10 \\
\hline Rs 4000-5000 & 31 & 6.2 & 35 & 7 \\
\hline $\begin{array}{l}\text { Rs 5000 and } \\
\text { above }\end{array}$ & 10 & 2 & 50 & 10 \\
\hline Total & 500 & $100 \%$ & 500 & $100 \%$ \\
\hline
\end{tabular}

The above table shows perception of the respondents on Monthly Expenditure ranges categorized. It is observed from the Pre-SHG 50 
study that the maximum percentage of respondents (77\%) had Below Rs 1000 and the next highest was observed that only about $8 \%$ who are spending between Rs3000-4000. 1\% of the respondents are spending between Rs 1000-2000, about $6.2 \%$ are spending Rs $4000-5000$, and $10 \%$ are spending Rs 5000 and above. Among the Post-SHG, the study revealed that the maximum percentage of respondents $(62 \%)$ is able to make a monthly expenditure of below Rs 1000. The expenditure level of the respondents are gradually increasing in the expenditure range between Rs 1000-2000, 2000$3000,3000-4000$, and 4000-5000. There is no increase or decrease of expenditure of Rs 5000 and above. There is an overall increase in expenditure level when compared with Pre-SHG period. It is inferred from the study that the spending capacity of the respondents has increased after joining the groups.

Table 11: Chi-square test for monthly expenditure before and after joining to SHGs

\begin{tabular}{|l|c|c|}
\hline \multicolumn{3}{|c|}{ Pearson Chi-Square Tests } \\
\hline & Chi-square & 45.75 \\
Monthly Expenditure - Pre- & & \\
\cline { 2 - 3 } SHG and Post SHG & Df & 5.00 \\
\cline { 2 - 3 } & Sig. & $0.00^{*}$ \\
\hline
\end{tabular}

Results are based on nonempty rows and columns in each innermost subtable.

*The Chi-square statistic is significant at the 0.05 level.

The above result may be interpreted that Monthly Expenditure seems to be influenced between Pre-SHG and Post SHG. Chi Square value showed 45.75 and sig value is. 0.00 , thus it is significant at 0.05 levels. The results imply that there is dependency between Pre-SHG and Post SHG with respect to Monthly Expenditure categorized. 


\section{Findings of the study}

Before becoming the members of SHGs, the people used to borrow from money lenders, friends and relatives. Majority of the people $(85 \%)$ used to borrow from money lenders. They used to charge exorbitant interest rates. But, after joining the SHGs, the group members used to borrow loans from the groups which were linked by the commercial banks. Thus, the poor people are also able to avail institutional loans through SHG - bank programmes which result into financial inclusion.

The impact of savings, standard of living, and other benefits accrued by the members after joining the groups also studied. All the members have started saving some amount after joining the SHGs. Of course the range of savings differs. The increase in saving is one important healthy indicator of economic prosperity. The change in the level of savings before joining the SHG and after joining the SHG is note worthy feature to study the impact of SHG.

The increase in the income, if followed by all increase in savings results in sustainable increase in standard of living both at macro lend and micro lend.

Standard of living of the members also improved after joining the groups. They possess almost the modern house hold appliances and their spending capacity also increased. After becoming the group members, they derived so many other benefits such as developing the saving habits, got better status in the family and society, developed self confidence, and better decision making power, etc.

The economic and social status of the members gradually increased after joining SHGs. All the members cultivated the habit of savings and such saved money got utilized for income generating activities. This enhanced their additional income. When they are able to earn additional income, in addition to their regular income, they could become free from debts. When they are free from debts, they could access resources.

The improvement in the economic status automatically led to the improvement in the social status also. The members were got recognition in the family as well as society. Economic 52 
independence made them take important decisions in family matters. This ultimately improved their self-confidence and enabled them to make social participation like contesting for local elections, taking up the profitable projects in the villages, etc. Thus, the SHG programme resulted into empowerment of women. The SHG can act as an alternative institutional setup to tackle the problems of unemployment, poverty, and gender justice. All these things could become possible, only because of the inclusive growth.

\section{Conclusion}

It is becoming increasingly apparent that addressing financial inclusion will require a holistic approach on the part of the banks in creating awareness about financial products, education and advice on money management, debt counselling, savings, and affordable credit. The banks would have to evolve specific strategies to expand the outreach of their services in order to promote Financial Inclusion. One of the ways in which it can be achieved in cost effective manner is through forging linkages with Micro Finance Institutions and social communities.

India is becoming one of the largest micro finance markets in the world especially in the growth of women's savings and credit groups Self Help Groups (SHGs) and sustaining success of such institutions which are playing crucial role in Financial Inclusion.

The main reason for financial exclusion is the lack of a regular or substantial income. In most of the cases people with low income do not qualify for loan. Most of the excluded consumers are not aware of the bank's products which are beneficial for them. Getting money for their financial requirements from a local money lender is easier than getting the loan from the bank. Most of the banks need collateral for a bank loan. Moreover banks give more importance to meeting their financial targets, so they focus on larger accounts. It is not profitable for banks to provide small loans and make a profit. Where the banks feel non-remunerative to lend in such places. Micro Finance Institutions are lending and struggling to bring more and more excluded people to its ambit.

Financial Inclusion mainly focuses on the poor who do not have formal financial support and getting them out of the clutches of 
local money lenders. Banks are now permitted to utilize the services of Non Government Organisation, Self Help Groups (SHGs), and other civil society organisations as intermediaries in providing financial and banking services through the use of business facilitator and business corresponding models.

SHGs are playing a very important role in the process of Financial Inclusion. SHGs groups of women are the ones who get together and pool money from their savings and lend money out of the savings. Usually they are working with the support of an NGO. The SHG is given loans against the group member's guarantee. Peer pressure within the group helps in improving recoveries. Through SHGs nearly 40 million households are linking with the banks. SHG-bank linkage is a strong tool which links low income groups to the bank.

Financial Inclusion is a great step to alleviate poverty in India, and such inclusion is taking place more and more with the help of Micro Finance. Some Micro Finance Institutions are acting as business facilitators/correspondents to bankers, and SHG-bank linkage programme linking the low income group people with banks. Thus, Micro Finance directly and indirectly is playing crucial role in financial inclusion.

\section{References}

Gurmeet, S. (2009). Micro finances an innovation in rural credit system. Kurukshetra, 57(4), 3-6.

Hemasundara, R. K., Munirami, R. M., \& Bhagavan, R. B. (2009). Out reaching unbanked rural marginalised groups. Kurukshetra, 57, 3-6.

Kala, G. S., (2004). Economic empowerment of women through self-help groups. Kisan World, 31(11), 25-26.

Ledgerwood, J., \& Victoria, W. (2006).Transforming microfinance institutions: Providing full financial services to the poor. World Bank.

Muhammad, Y. (2003). Banker to the poor: Micro-lending and the battle against world poverty, Public affairs.

Muhammad, Y. (2009). Creating a world without poverty: social business and the future of capitalism. Public affairs.

Raghavendra, K., (2003), Self-help group linkage banking - challenges of training- role played by national centre. Lead Bank Journal, 41(4), 72-76. 
Smith, D. H., \& Pillheimer, K., (1983). Self help groups as social move organizations: Social structure \& social change. Research in social movement. Conflicts $\mathcal{E}$ Change, 5(2), 35.

Thelmakay. (2005). Empowering women through self-help micro credit programmes- in a micro credit in Asia concepts $\mathcal{E}$ cases (Rajashri, G., Ed.). ICFAI University books, 83-94.

Velu, S. K. A., Thaha, S. \& Karuppiah, M. (2010). SHGs: Micro finance strategy in empowering rural women. Southern Economist, 49(7), 37-40.

Venkatesh. M., \& Dinesh, G. M. (2011). SHGs and empowerment of women. Southern Economist, 49(18), 35-39. 